\title{
Article \\ Application of a device for the production of electrovalves by High Speed Friction Welding HSFW and FSW welding
}

\author{
Damian Miara1, $^{1,}$, Jolanta Matusiak ${ }^{1}$, Adam Pietras ${ }^{1}$, Mateusz Świetlik ${ }^{2}$, Saverio Zitti ${ }^{3}$ \\ ${ }^{1}$ Research Network ŁUKASIEWICZ - Welding Institute, Poland \\ Jolanta Matusiak, Ph.D.; jolanta.matusiak@is.gliwice.pl; \\ Adam Pietras, Ph.D.; adam.pietras@is.gliwice.pl; \\ 2 Zannini Poland Sp. z o.o., Poland \\ Mateusz Świetlik, M.Sc.; mateusz.swietlik@zannini.com; \\ ${ }^{3}$ Zannini Spa, Castelfidardo AN, Italy \\ Saverio Zitti, M.Sc.; saverio.zitti@zannini.com; \\ * Correspondence: Damian Miara, M.Sc.; damian.miara@is.gliwice.pl
}

Received: 13.08.2019; Accepted: 10.10.2019

\begin{abstract}
In order to meet the current requirements of the automotive industry, associated with the creation of a machining center for the production of cylindrical welded and turned components for the construction of solenoid valves, innovative technologies are needed for joining different materials of construction. The article presents the results of the research on the applicability, production of steel electrovalves elements in the AISI303 and 11SMnPb30 grades, an innovative solution consisting in the combination of HSFW high speed friction welding and friction welding using the FSW method. As part of the research, inter alia, a welding station, selection of the shape and dimensions of tools, selection of welding parameters for the HSFW / FSW method, and tests of mechanical properties of the resulting joints were carried out. The obtained results indicate that the obtained connections are characterized by high and reproducible quality.
\end{abstract}

Keywords: friction welding; FSW; high speed friction welding; HSFW; electrovalves welding

\section{Introduction}

The article presents the results of research conducted at the Institute of Welding as part of a project implemented in the company Zannini Poland Sp. z o.o.: "An innovative technological solution consisting in a combination of friction welding technologies (Friction Stir Welding) and dry turning within one multitask machining center with a high level of environmental balance for the production of electrovalves for the automotive industry" [1]. The overall goal of the project was to develop a technology for the welding of electrovalve components to reduce the number of necessary operations to connect them, i.e. from two separate operations (state before project implementation) to only one innovative combined operation (state after project implementation) performed entirely at one multi-purpose center machining, thanks to which it will be possible to obtain directly a cylindrical component intended for the production of electrovalves for the automotive industry. The need to build such a machining center results from the demand from the automotive industry for cylindrical welded and turned components for the production of electrovalves. Currently, this type of cylindrical components, are made of two turned components made of different materials in successively performed operations:

1. the process of welding by brazing in a furnace performed by specialized companies providing machining services;

2. the turning process on a machine with a rotary spindle with intercept to make the final geometry necessary to use the element for the production of electrovalves.

High-speed friction welding (HSFW) is a solid state welding process and is one of the few examples of the use of frictional heat generated during a technological process that involves the direct conversion of mechanical energy into thermal energy [2,3]. A diagram of the high-speed friction welding process is shown in figure 1 . 


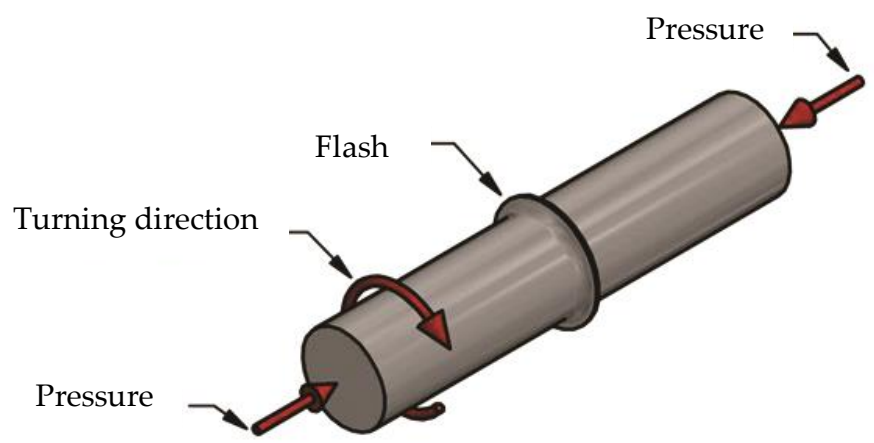

Fig. 1. Scheme of HSFW welding method

Friction welding machines recently proposed on the market allow welding at speeds of up to approx. $24000 \mathrm{rpm}$ [3]. The use of such high rotational speeds means that the joining conditions significantly change compared to conventional friction welding methods.

Special features of high-speed friction welding, such as a narrow deformation zone or minimal shortening of welded elements, allow this method to be used for joining dissimilar materials, even for materials with significantly different physical properties, e.g. austenitic with carbon steel, free-cutting steel with stainless steel, carbon steel with aluminum or aluminum with copper, metals with non-metals.

The process of joining metals by the friction stir welding method (FSW) is formed in a solid state $[4 \div 6]$. A rotating mixing tool [7:10], penetrating the material along the welding line, is used to heat and plasticize the frictional material. After setting the tool in rotational motion and heating with friction heat and plasticizing the material in the immediate vicinity of the tool, the entire system moves along the tool's trajectory [11:13]. The heated and plasticized material of the welded elements is squeezed around the mandrel backwards, where it is mixed together before it cools and compacted by the resistance rim [14,15]. FSW technology can also be used to change the structure of the material or to shape a connection made using other welding technology. The FSW welding scheme and directions of plasticized metal masses are shown in figure 2 .

The implementation of the combined technology HSFW + FSW for the production of electro-valves made of two different types of materials (different configuration of connections) will be significantly distinguished by the level of innovation on the market due to the lack of similar solutions and applications.

\section{Materials for research}

Technological tests of making connections of electro-valves using the combined HSFW + FSW technology were carried out using two steel grades: AISI303 and 11SMnPb30.

Stainless steel ALSI303 is a steel for hard drawn products that are produced and supplied in a series of special rods or flat bars. Typical ALSI303 steels used are engineering cylinders and hydraulic electrovalves and several subsystems in the automotive and heavy industries, including earthmoving machinery and lifting equipment. The chemical composition and basic mechanical properties of ALSI303 steel are presented in table I (according to ASTM A582, QQ-S-764).

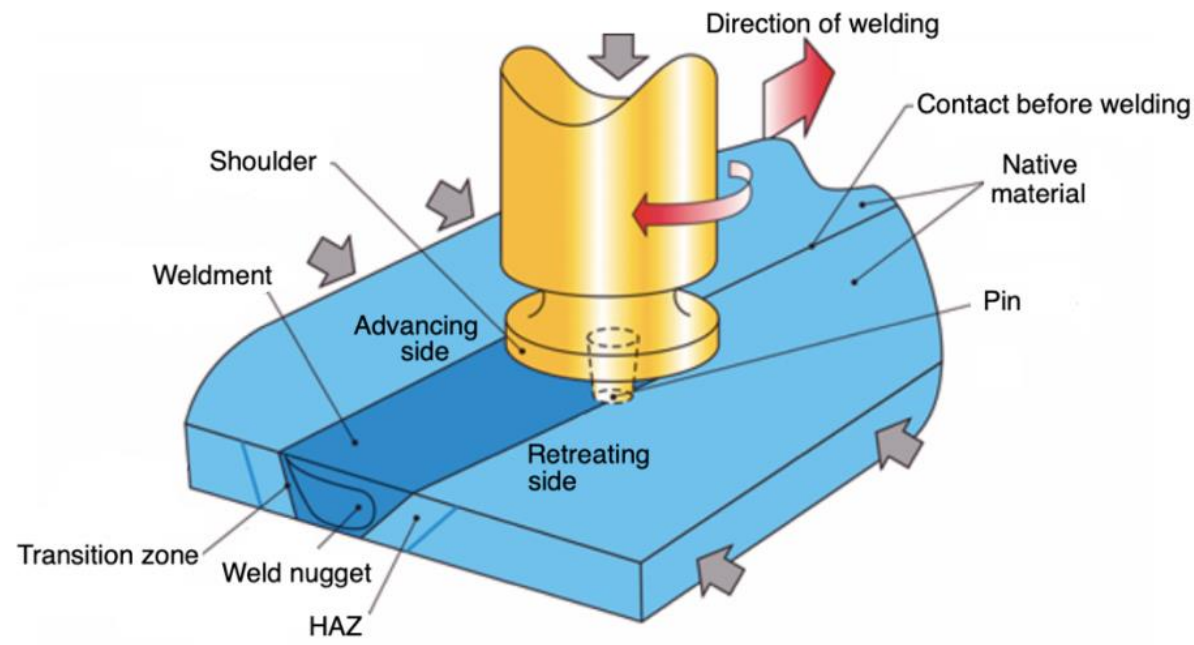

Fig. 2. Scheme of FSW welding method 
Table I. Chemical composition and basic mechanical properties of ALSI303 steel

\begin{tabular}{cccccccccc}
\hline \multirow{2}{*}{ Designation } & C & Cr & Si & Mn & Mo & Ni & P & S & Fe \\
\hline ALSI303 & $\leq 0.15$ & 18 & $\leq 1.0$ & $\leq 2.0$ & $\leq 0.6$ & 9.0 & $\leq 0.2$ & $\geq 0.15$ & rest \\
\hline \multicolumn{10}{c}{ Young's modulus: $193 \mathrm{GPa}$} \\
Tensile strength: $415 \mathrm{MPa}$ \\
Yield point: $240 \mathrm{MPa}$ \\
\hline
\end{tabular}

Free-cutting steel 11SMnPb30 is a steel for elements for the production of bolts, nuts, washers, hydraulic hose ends, electro-valves, etc. Such, steel supplied in the form of mostly drawn or peeled bars. The chemical composition and basic mechanical properties of $11 \mathrm{SmnPb30}$ steel are presented in Table II (in accordance with EN 10087).

Table II. Chemical composition and basic mechanical properties of $11 \mathrm{SMnPb} 30$ steel

\begin{tabular}{cccccccccc}
\hline \multirow{2}{*}{ Designation } & C & Cr & Si & Mn & Mo & Ni & P & S & Fe \\
\hline $11 \mathrm{SMnPb} 30$ & $\leq 0.15$ & - & $\leq 0.05$ & $0.9-1.3$ & - & - & $\leq 0.11$ & $0.27 \div 0.33$ & rest \\
\hline \multicolumn{8}{c}{ Young's modulus: $210 \mathrm{GPa}$} \\
Tensile strength: $460 \mathrm{MPa}$ \\
Yield point: $375 \mathrm{MPa}$ \\
\hline
\end{tabular}

\section{Research workstation}

In order to fully approach the current conditions of connecting the solenoid valves (by soldering and laser welding), HSFW welding tests used rods with a diameter of $10 \mathrm{~mm}$, which after HSFW welding can be processed to shape the weld created using FSW technology (combined technology HSFW + FSW).

The tests of the HSFW welding process of the electro-valves were carried out on a high-speed RSM 400 welding machine from the German company Harms \& Wende together with the control system (Fig. 3). In the first stage, bars made of 11SMnPb30 steel and ALSI303 steel were welded, and then a part of the bar was cut off from the bar made of ALSI303 steel, the next stage of the process was welding the resulting element with a bar made of $11 \mathrm{SMnPb30}$ steel. The scheme for the preparation of subsequent stages of highspeed HSFW welding of electro-valves is shown in Figure 4. The HSFW friction welding process was carried out (for 10 sets of ready connections) using rotational speed, $V_{n}=20000 \mathrm{rpm}$; friction pressure, $F_{t}=610$ daN; upsetting pressure, $F_{s}=910$ daN; friction time, $t_{t}=4 \mathrm{~s}$, upsetting time, $t_{s}=2 \mathrm{~s}$. The welding parameters were selected on the basis of previous experience related to welding of other construction materials. Selected samples were subjected to further non-destructive and destructive tests.
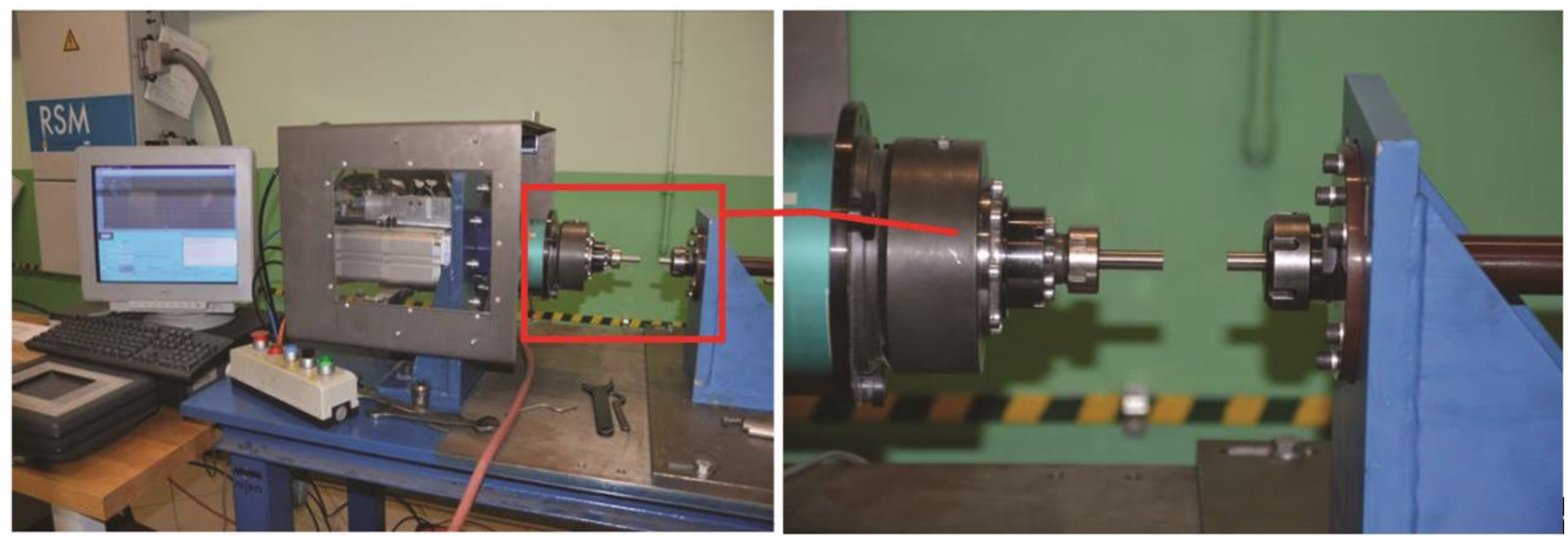

Fig. 3. HSFW welding station - RSM 400 high-speed welding machine from Harms \& Wende with attached materials for the production of electro-valves

As part of making electro-valves elements using combined technology (HSFW + FSW), forming of the welded surface using HSFW technology was carried out with the use of the FSW tool shifted with an axis. An AVIA numerically controlled milling machine equipped with a specially designed rotator was used to shape the HSFW flow using FSW technology. 


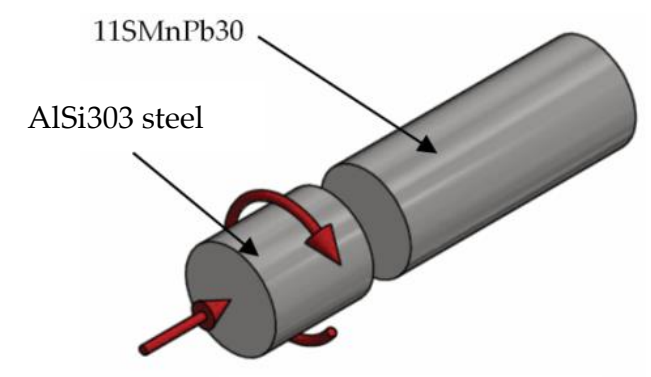

Befor welding - stage 1

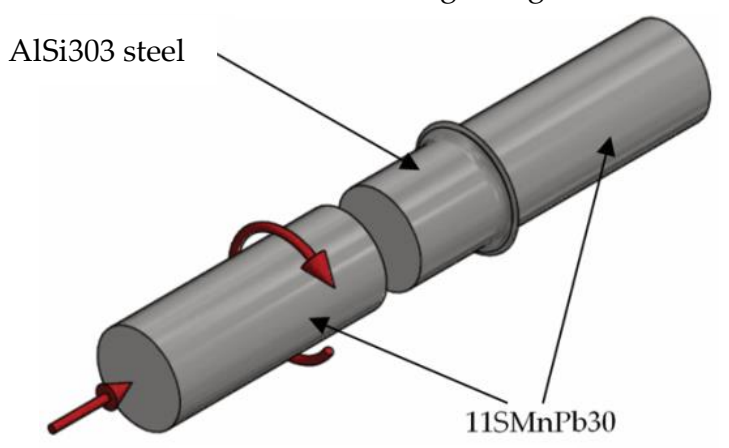

During welding - stage 3

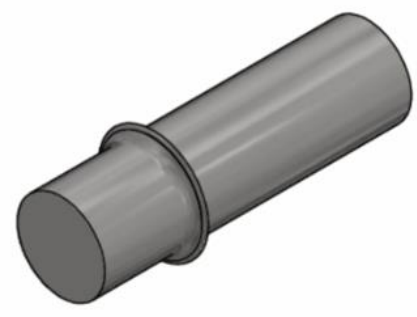

During welding - stage 2

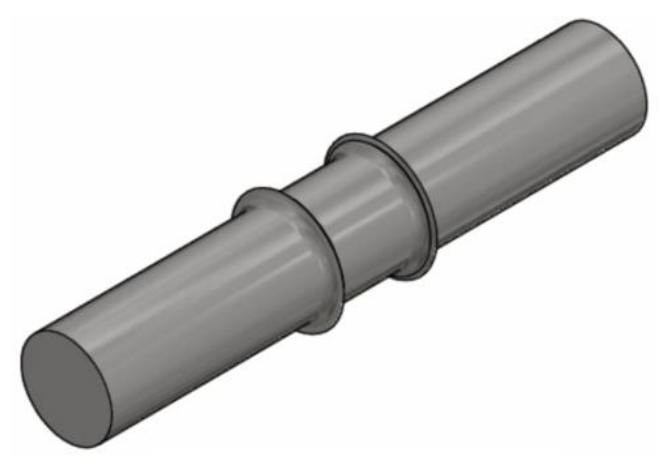

After welding - stage 4

Fig. 4. Scheme of preparation of HSFW welding stages of electrovalve elements

A diagram of the process of shaping the HSFW flash using an FSW offset tool with an axis is shown in figure 5, while figure 6 shows a view of this process.

In order to determine the impact of FSW process parameters on the material mixing method, macro- and microscopic metallographic tests of selected welds in accordance with standard 17639:2013-12 were carried out on the cross-sections of the joints. In order to determine the strength properties of HSFW friction welds after flash treatment with the FSW tool, a static tensile test was carried out according to PN-EN ISO 4136:2013-05E. In order to determine the strength properties of HSFW friction welds after flash treatment with the FSW tool, a bending test was carried out according to PN-EN ISO 5173:2010/A1:2012.
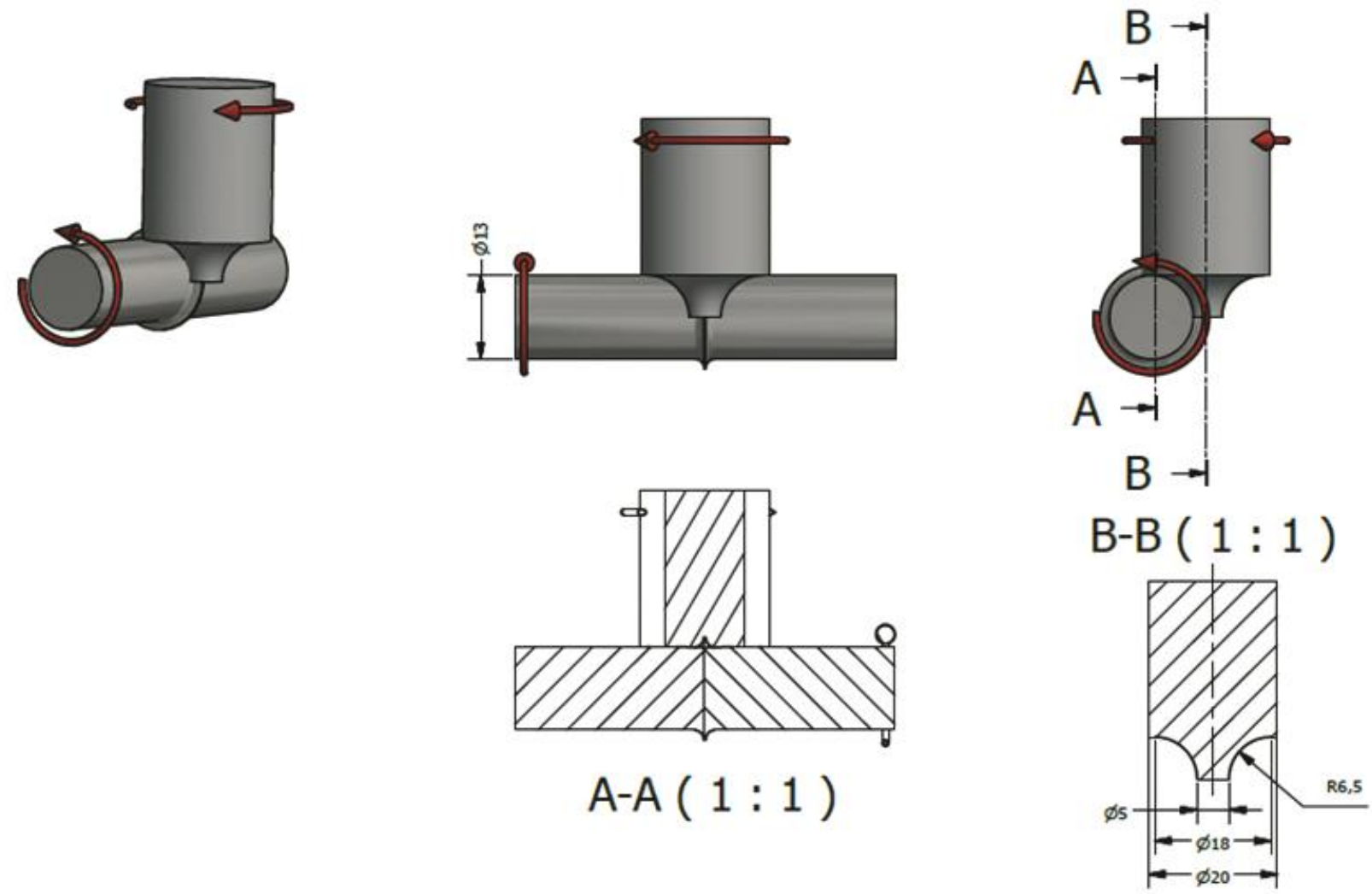

Fig. 5. Scheme of the HSFW flash shaping process using an FSW offset tool with an axis 

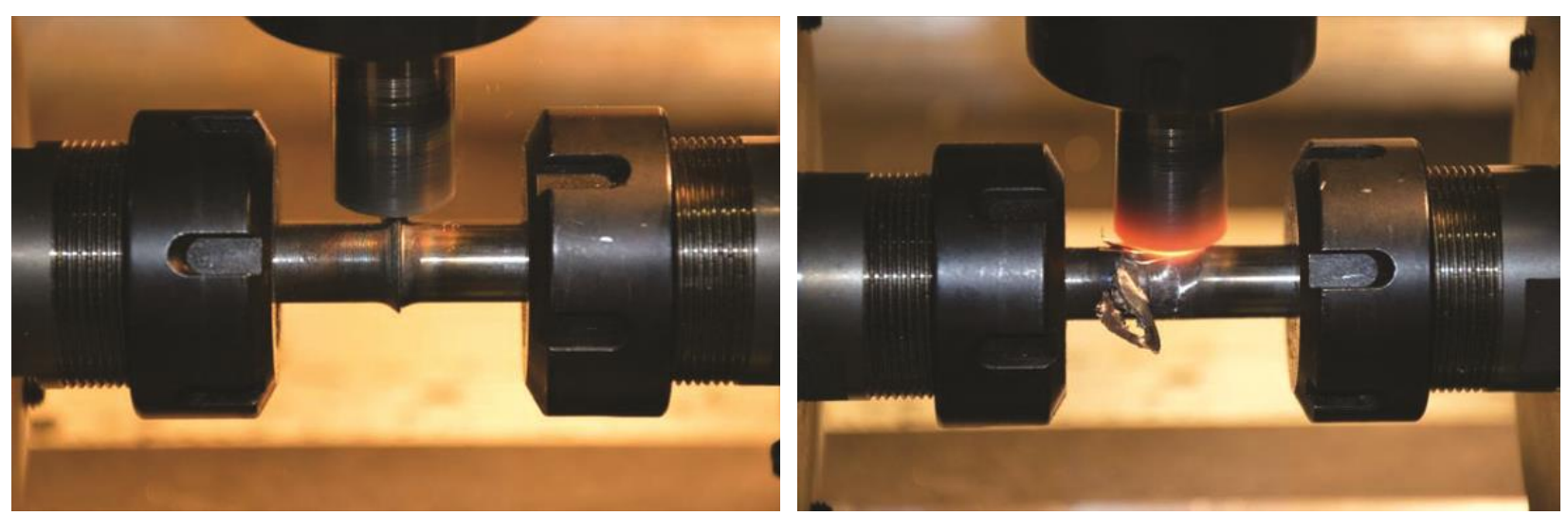

Fig. 6. View of the process of shaping the HSFW flash with the FSW offset tool with an axis: a) the beginning of the flashing process, $b$ ) the flash forming process

\section{Research results}

\section{Visual testing}

The view of HSFW friction welds is shown in Figure 7. The view of HSFW friction welds machined with the FSW tool with the mandrel is shown in Figure 8.

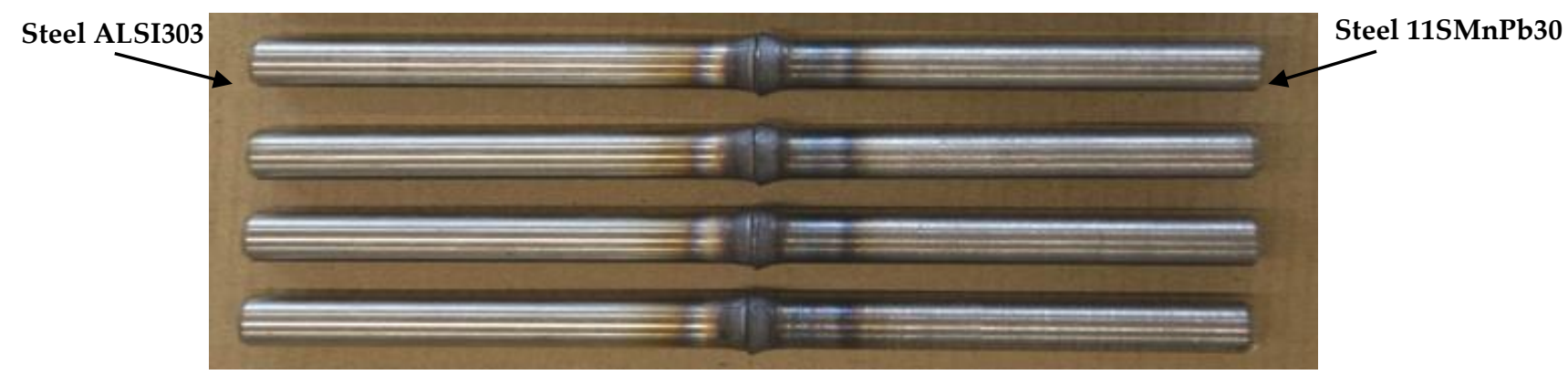

Fig. 7. View of HSFW welds

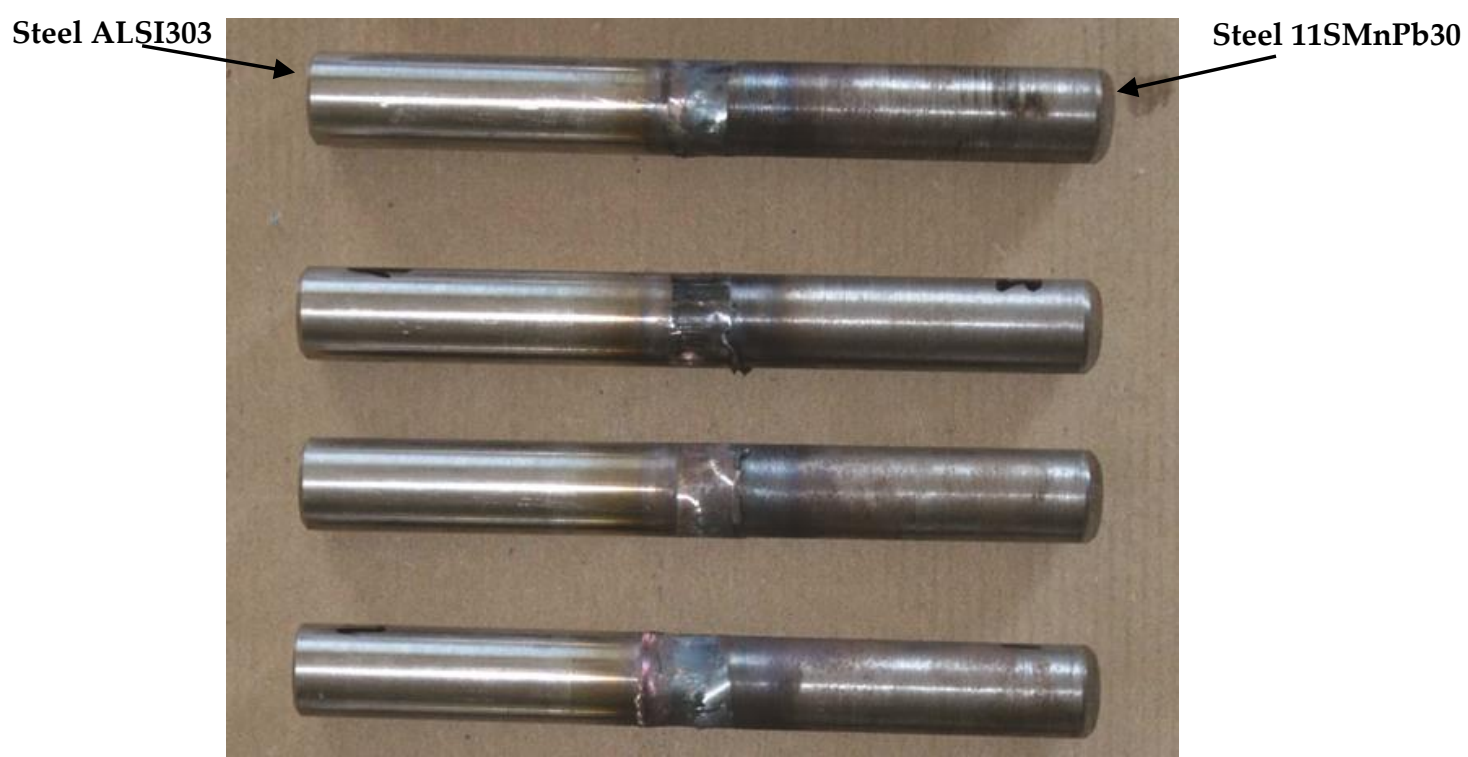

Fig. 8. View of HSFW welds shaped by FSW offset tool with an axis

The results of visual tests of HSFW friction welds indicate that the welds have a regular shape characteristic for friction welding technology, and the size of the flash and the temperature area of the welding process depends on the duration of the welding process.

\section{Macroscopic metallographic tests}

Figure 9 shows the macrostructure of the selected HSFW weld for 11SMnPb30 steel + ALSI303 steel. Figure 10 shows the macrostructure of two HSFW welds made as a combination of three elements, i.e. $11 \mathrm{SMnPb} 30$ steel + ALSI303 steel + 11SMnPb30 steel after machining with the FSW offset tool with an axis. 


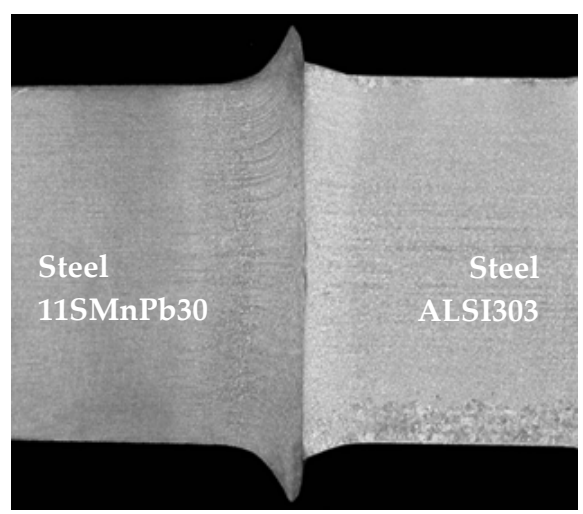

Fig. 9. Macrostructure of HSFW weld from ALSI303 and 11SMnPb30 steel. machined with an FSW offset tool with an axis

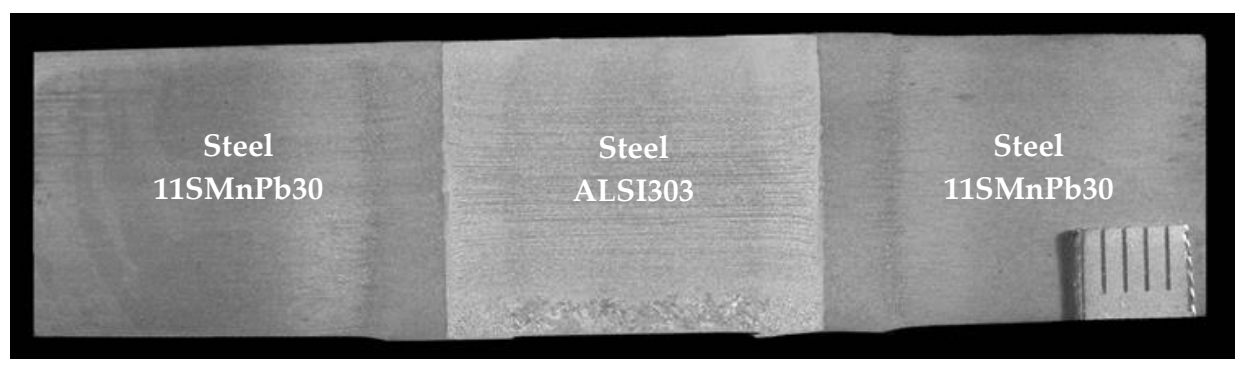

Fig. 10. Macrostructure of two HSFW welds welded as a set i.e. steel $11 \mathrm{SMnPb} 30+$ ALSI303 steel + steel $11 \mathrm{SMnPb30}$ and machined with the help of the FSW tool with a pin

The results of macroscopic metallographic tests indicate the correct mixing of materials in the joining zone, there are no traces of occurrence of internal structural incompatibilities.

Examples of microstructure of HSFW welds machined with the FSW tool are shown in figure 11.

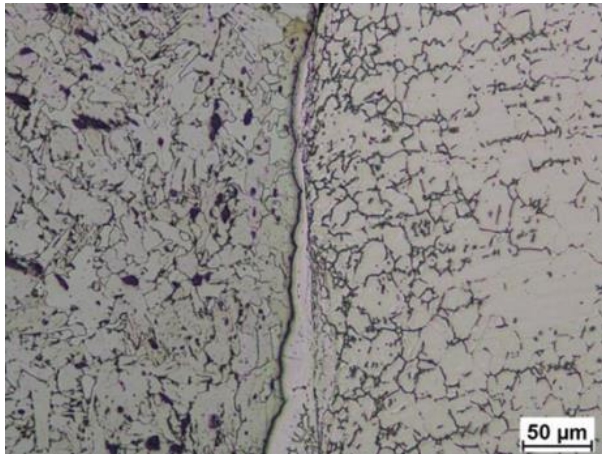

Welding zone

(a)

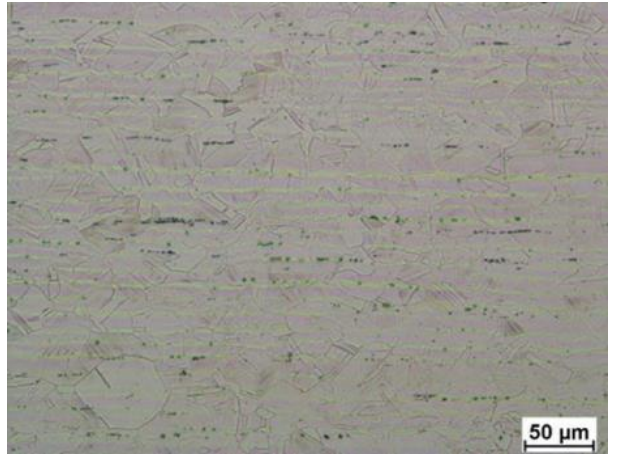

ALSI303 steel structure

(b)

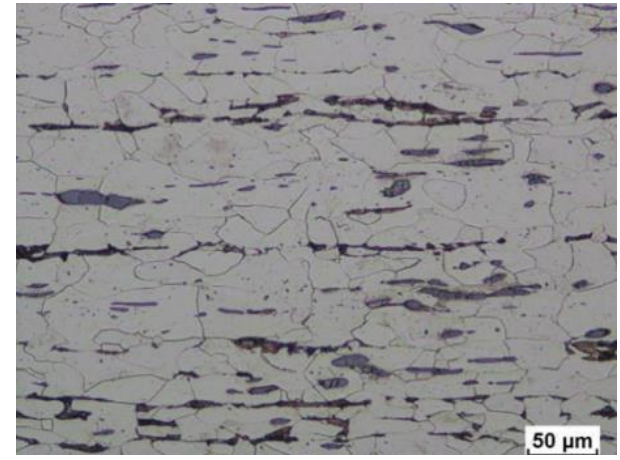

$11 \mathrm{SMnPb} 30$ steel structure

(c)

Fig. 11. HSFW weld microstructures made of ALSI303 and 11SMnPb30 steel machined by FSW tool

The weld microstructures presented indicate the typical structure of both steel grades used for testing. ALSI303 steel is a typical austenitic structure with twins (Fig. 11b). In turn, $11 \mathrm{SMnPb30}$ steel has a ferriticpearlitic structure in a band system. Sulfur-based precipitations responsible for improving the machinability of this material are also visible (Fig. 11c).

\section{Tensile strength tests}

The results of tests on the tensile strength of HSFW welds machined with the FSW offset tool with an axis, are shown in Table III.

The results of tests on the tensile strength of HSFW welds indicate high and reproducible quality of welds obtained. The average strength for specimens with flash treatment using the FSW offset tool with an axis is about $448.4 \mathrm{MPa}$. In each case, the break in the tensile test occurred in the weld. In the test program it was assumed that the welds tensile strength tests would be carried out for connections with the machined flash. Strength tests were not carried out for native materials due to the small dimensions of the components of electro-valves. 
Table III. The results of tensile strength tests of HSFW welds machined by FSW offset tool with an axis

\begin{tabular}{ccccc}
$\begin{array}{c}\text { Sample } \\
\text { No. }\end{array}$ & $\begin{array}{c}\text { Rotation speed } \\
\mathbf{V}_{\mathbf{n}, \mathbf{r p m}}\end{array}$ & $\begin{array}{c}\text { Welding speed } \\
\mathbf{V}_{\mathbf{z}}, \mathbf{m m} / \mathbf{m i n}\end{array}$ & $\begin{array}{c}\text { Tensile strength } \\
\mathbf{R}_{\mathbf{m}}, \mathbf{M P a}\end{array}$ & $\begin{array}{c}\text { Average tensile } \\
\text { strength } \\
\mathbf{R}_{\mathbf{m}}, \mathbf{M P a}\end{array}$ \\
\hline 8 & & & 429.3 & \\
9 & 4000 & 82 & 445.6 & 448.4 \\
10 & & & 470.4 & \\
\hline
\end{tabular}

\section{Bending strength tests}

The results of tests on the bending strength of HSFW welds machined with the FSW offset tool with an axis are presented in Table IV. In each case, the average values of the bending angles are repeatable and in this case they are $15.0^{\circ}$.

Table IV. The results of tensile strength tests of HSFW welds machined by FSW offset tool with an axis

\begin{tabular}{ccccc}
\hline $\begin{array}{c}\text { Sample } \\
\text { No. }\end{array}$ & $\begin{array}{c}\text { Rotation speed } \\
\mathbf{V}_{\mathbf{n}, \mathbf{r p m}}\end{array}$ & $\begin{array}{c}\text { Welding speed } \\
\mathbf{V}_{\mathbf{z}}, \mathbf{m m} / \mathbf{m i n}\end{array}$ & $\begin{array}{c}\text { Bending angle, } \\
{ }^{\prime}\end{array}$ & $\begin{array}{c}\text { Average bending } \\
\text { angle }^{\circ}{ }^{\circ}\end{array}$ \\
\hline 11 & & & 15.0 & \\
12 & 4000 & 82 & 15.0 & 15.0 \\
13 & & & 15.0 & \\
\hline
\end{tabular}

\section{Conclusions}

1. Based on the conducted tests, it was demonstrated that the combination of high-speed friction welding technology HSFW with the formation of a weld using friction welding technology with material mixing FSW is an innovative solution for use in connecting electrovalves.

2. The selection of appropriate parameters of the HSFW high-speed friction welding process allowed to obtain high quality welded joints, which is confirmed by the results of friction weld tensile strength tests and macroscopic metallographic tests.

3. The use of FSW offset tool with an axis, and the selection of appropriate technological parameters of the process for forming the weld after the HSFW method enabled obtaining repeatable welds of electrovalves.

Conflicts of Interest: The authors declare no conflict of interest.

Author Contributions: conceptualization M.B. and J.S., methodology M.B. and J.S.; investigation M.B.; discussion M.B. and J.S., writing-original draft preparation M.B. and editing J.S.

\section{References}

[1] Miara D., Matusiak J., Pietras A., Development and implementation of an experimental stand at the Welding Institute for testing and development of welding technology for solenoid valves and welding tests for the FSW and HSFW / FSW methods, Sprawozdanie z pracy badawczej Instytutu Spawalnictwa nr B-303/18 (Bb-127), 2018, Gliwice.

[2] Poradnik Inżyniera - Spawalnictwo, Wydawnictwo Naukowo Techniczne, T. 2, 2007, Warszawa.

[3] Zadroga L., Pietras A., Papkala H., Study of conditions for joining different materials by modern friction welding methods, Sprawozdanie z pracy badawczej Instytutu Spawalnictwa, 2004, Gliwice.

[4] Miara D., Matusiak J., High speed FSW welding of wrought aluminium alloy, Welding Technology Review, 2017, Vol. 89(10), 27-31. [CrossRef]

[5] Rajiv S., Mishra A., Murray W., Mahoney E., Friction stir welding and processing, ASM International, 2007.

[6] Kallee S.W., Nicholas E. D., Friction Stir Welding - the invention, innovation, implementation and industrialisation, $8^{\text {th }}$ Incalco International Conference of joint in aluminum, Munich, Germany, 2001.

[7] Rai R., De A., Bhadeshia H.K.D.H., DebRoy T., Review: friction stir welding tools, Journal Science and Technology of Welding and Joining, 2011, Vol. 16(4), 325-342. [CrossRef]

[8] Aroraa A., Deb A., DebRoya T., Toward optimum friction stir welding tool shoulder diameter, Scripta Materialia, 2011, Vol. 64(1), 9-12. [CrossRef]

[9] Li H., Gao J., Li Q., Galloway A., Toumpis A., Effect of friction stir welding tool design on welding thermal efficiency, Journal Science and Technology of Welding and Joining, 2018, Vol. 24(2). [CrossRef] 
[10] Shashi S., Kumara S., Murugan N., Ramachandranc KK., Microstructure and mechanical properties of friction stir welded AISI 316L austenitic stainless steel joints, Journal of Materials Processing Technology, 2018, Vol. 254, 79-90. [CrossRef]

[11] Liu F.C., Hovanski Y., Miles M.P., Sorensen C.D., Nelson T.W., A review of friction stir welding of steels: Tool, material flow, microstructure, and properties, Journal of Materials Science E Technology, 2018, Vol. 34(1), 39-57. [CrossRef]

[12] Tingeya C., Gallowaya A., Toumpisa A., Caterb S., Effect of tool centreline deviation on the mechanical properties of friction stir welded DH36 steel, Materials \& Design, 2015, Vol.65, 896-906. [CrossRef]

[13] Kailas V., Kumar K., The role of friction stir welding tool on material flow and weld formation, Materials Science and Engineering, 2008, Vol. 485(1-2), 367-374. [CrossRef]

[14] Sarkara R., Pala T.K., Shomeb M., Material flow and intermixing during friction stir spot welding of steel, Journal of Materials Processing Technology, 2016, Vol. 227, 96-109. [CrossRef]

[15] Micallef D., Camilleri D., Toumpis A., Galloway A., Arbaoui L., Local heat generation and material flow in friction stir welding of mild steel assemblies, Journal of Materials: Design and Applications, 2016, Vol. 230(2). [CrossRef]

(C) 2019 by the authors. Submitted for possible open access publication under the terms and conditions of the Creative Commons Attribution (CC BY) license (http://creativecommons.org/licenses/by/4.0/). 